2. David PB, Di Sant'Agnese PA 1980 A review. Cystic fibrosis at forty-quo vadis? Pediatr Res 14:83-87

3. Dearborn DG 1976 Water and electrolytes of exocrine secretions. In: Mangos JA and Talamo RC (eds) Cystic Fibrosis: Projections into the Future. Symposia Specialists, New York, pp 179-191

4. Knowles M, Gatzy $J$, Boucher $R 1981$ Increased bioelectric potential difference across respiratory epithelia in cystic fibrosis. N Engl J Med 305:1489-1495

5. Boucher RC, Stutts MJ, Knowles MR, Cantley L, Gatzy JT $1985 \mathrm{Na}^{+}$transport in cystic fibrosis nasal epithelia: abnormal basal rate and response to adenylate cyclase activation. Clin Res 33:467A

6. Knowles MR, Stutts MJ, Spock A, Fischer N, Gatzy JT, Boucher RC 1983 Abnormal ion permeation through cystic fibrosis respiratory epithelium. Science 221:1067-1070

7. Knowles M, Gatzy J Boucher R. 1983 Relative ion permeability of normal and cystic fibrosis nasal epithelium. J Clin Invest 71:1410-1417

8. Laragh JH, Sealey JE 1973 The renin-angiotensin-aldosterone hormonal system and regulation of sodium, potassium, and blood pressure homeostasis. In: Orloff J, Berliner RW (eds) Handbook of Physiology. Section 8: Renal Physiology. American Physiological Society, Washington, DC, pp 831-908

9. Fordtran JS, Ingelfinger FJ 1968 Absorption of water, electrolytes, , and sugars from the human gut. In: Code CF (ed) Handbook of Physiology, Section 6; Alimentary Canal, Vol IIl, Intestinal Absorption. American Physiological Society, Washington, DC, pp 1457-1490

10. Forman Barr H, Mulrow PJ 1976 Effect of corticosteroids on water and electrolyte metabolism. In: Greep RO, and Astwood EB (eds) Handbook of Physiology, Section 7-Endocrinology, Vol VI. American Physiological Society, Washington, DC, pp 179-189

11. Frizzell RA, Schultz SG 1978 Effect of aldosterone on ion transport by rabbit colon in vitro. J Membrane Biol 39:1-26

12. Hopfer U, Will PC, Dearborn DG 1980 Cystic fibrosis: a secondary endocrine or target tissue sensitivity problem in epithelial electrolyte transport? In:
Perspectives in Cystic Fibrosis, Proceedings of the 8th International Congress on Cystic Fibrosis. Toronto, Canadian Cystic Fibrosis Foundation, p 20A

13. Edmonds CJ 1970 Measurement of rectal electrical potential difference as an instant screening-test for hyperaldosteronism. Lancet 2:624-627

14. Rask-Madsen J, Schiotz PO, Bartels U, Nielsen MD, Becher-Christensen F 1975 Electrical polarization of rectal mucosa and excretion of tetrahydroaldosterone in patients with cystic fibrosis of pancreas and in normal subjects. Acta Paediatr Scand 64:81-86

15. Montalvo JM, McCaa CS, Cole WQ 1967 Aldosterone metabolism in children with cystic fibrosis and their parents. J Endocrinol Metab 28:582-585

16. Orenstein DM, Henke KG, Costill DL, Doershuk CF, Lemon PJ, Stern RC 1983 Exercise and heat stress in cystic fibrosis patients. Pediatr Res 17:267269

17. Haschke F, Gotz M, Parth K, Popow C, Schilling R 1981 Plasma aldosterone elevation due to renal sodium wasting in a boy with cystic fibrosis. Acta Paediatr Scand 70:763-764

18. Rapaport R, Levine LS, Petrovic M, Wilson T, Draznin M, Bejar RL, Johanson A, New MI 1981 The renin-aldosterone system in cystic fibrosis. J Pediatr 98:768-771

19. Simopoulos AP, Lapey A, Boat TF, di Sant'Agnese PA, Bartter FC 1971 The renin-angiotensin-aldosterone system in patients with cystic fibrosis of the pancreas. Pediatr Res 5:626

20. Knowles MR, Gatzy JT, Boucher RC 1982 Spironolactone effects on epithelia potential difference and aldosterone excretion in cystic fibrosis. In: Cystic Fibrosis Club Abstracts, Twenty-Third Annual Meeting. Washington, DC, Cystic Fibrosis Foundation, p 43

21. Boucher RC, Gatzy JT 1983 Characteristics of sodium transport by excised rabbit trachea. J Appl Physiol 55:1877-1883

22. Legris GJ, Will PC, Hopfer U 1982 Inhibition of amiloride-sensitive sodium conductance by indoleamines. Proc Natl Acad Sci USA 79:2046-2050

\title{
Whole Body Protein Synthesis and Energy Expenditure in Very Low Birth Weight Infants
}

\author{
C. CATZEFLIS, Y. SCHUTZ, J.-L. MICHELI, C. WELSCH, M. J. ARNAUD, AND E. JÉQUIER \\ Institute of Physiology, Faculty of Medicine, University of Lausanne, Lausanne [C.C., Y.S., E.J.]; Service of \\ Paediatrics, University Hospital, CHUV, Lausanne [J.-L.M.]; and Nestlé Products Technical Assistance Co. Ltd., \\ Research Department, La Tour-de-Peilz [C.W., M.J.A.], Switzerland
}

\begin{abstract}
The aim of the present work was to study whole body protein synthesis and breakdown, as well as energy metabolism, in very low birth weight premature infants $(<1500 \mathrm{~g})$ during their rapid growth phase. Ten very low birth weight infants were studied during their first and second months of life. They received a mean energy intake of $114 \mathrm{kcal} / \mathrm{kg}$. day and $3 \mathrm{~g}$ protein $/ \mathrm{kg}$. day as breast milk or milk formula. The average weight gain was $15 \mathrm{~g} /$ $\mathrm{kg} \cdot \mathrm{day}$. The apparent energy digestibility was $88 \%$, i.e. 99 $\mathrm{kcal} / \mathrm{kg}$ - day. Their resting postprandial energy expenditure was $58 \mathrm{kcal} / \mathrm{kg} \cdot$ day, indicating that $41 \mathrm{kcal} / \mathrm{kg} \cdot$ day was retained. The apparent protein digestibility was $89 \%$, i.e. $2.65 \mathrm{~g} / \mathrm{kg}$. day. Their rate of protein oxidation was 0.88 $\mathrm{g} / \mathrm{kg} \cdot$ day so that protein retention was $1.76 \mathrm{~g} / \mathrm{kg} \cdot$ day. There was a linear relationship between $N$ retention and $\mathrm{N}$ intake $(r=0.78, p<0.001)$. The slope of the regression line indicates a net efficiency of $N$ utilization of $67 \%$. Estimates of body composition from the energy balance,
\end{abstract}

Received July 20, 1984; accepted February 27, 1985.

Correspondence to Prof. E. Jéquier, Institute of Physiology, Universiy of Lausanne, Rue du Bugnon 7, CH-1011 Lausanne, Switzerland. coupled with $\mathbf{N}$ balance method, showed that $25 \%$ of the gain was fat and $75 \%$ was lean tissue. Whole body protein synthesis and breakdown were determined using repeated oral administration of ${ }^{15} \mathrm{~N}$ glycine for $60-72 \mathrm{~h}$, and ${ }^{15} \mathrm{~N}$ enrichment in urinary urea was measured. Protein synthesis averaged $11.2 \mathrm{~g} / \mathrm{kg}$. day and protein breakdown $9.4 \mathrm{~g} /$ $\mathrm{kg}$-day. Muscular protein breakdown, as estimated by 3methylhistidine excretion, contributed to $12 \%$ of the total protein breakdown. There was a positive correlation $(r=$ $0.68, p<0.05$ ) between protein synthesis and protein gain, as well as between resting energy expenditure and protein gain $(r=0.58, p<0.01)$. The slope of the regression line indicated that $1 \mathrm{~g}$ of protein gain required the synthesis of five times more protein $(5 \mathrm{~g})$ and resulted in an extra energy expenditure of $10 \mathrm{kcal}$. Thus, the net cost of protein synthesis in these very low birth weight infants was $2 \mathrm{kcal} /$ g. (Pediatr Res 19: 679-687, 1985)

\section{Abbreviations}

3-MHis, 3-methylhistidine 
Very low birth weight infants (birth weight $<1500 \mathrm{~g}$ ) represent a veritable challenge to neonatal medicine and nutrition. In addition to common early medical complications (i.e. respiratory distress) very low birth weight infants present gastrointestinal immaturity and limited protein and energy reserves. In an attempt to achieve growth rate similar to that obtained in intrauterine infants, very low birth weight infants are fed a substantial amount of food energy. The disposal of energy intake in these infants has been the object of a limited number of investigations $(1,2)$. These studies have shown that during the rapid growth period, the energy expenditure per kilogram of body weight is elevated, as compared to values published for full term infants (1-3). The question arises whether this high metabolic rate is due to the energy cost of growth, particularly the cost of protein synthesis.

Dynamic aspects of protein metabolism can be studied by using nonradioactive, stable ${ }^{15} \mathrm{~N}$ labeled amino acids as biological markers (4-7). Whole body protein synthesis and protein breakdown in very low birth weight infants reared either on human milk (5), various "humanized" cow milk $(6,7)$, or given total parenteral nutrition (4) were found to be elevated in all situations. Since protein synthesis is known to entail a considerable amount of energy expenditure for the formation of peptide bonds, it is of interest to determine whether there is a relationship between the rate of protein synthesis and the amount of energy expended by very low birth weight infants. This approach can also be used to obtain the energetic cost of protein synthesis in these infants.

\section{MATERIALS AND METHODS}

Infants. Ten very low birth weight infants admitted to the neonatal intensive care unit of the University Hospital were studied. Their birth weight ranged from 950-1420 g and their gestational age between 28-31 wk, confirmed by Dubowitz score (8). All were appropriate weight for gestational age and were free of any major medical problem at the time of the study. The clinical and growth characteristics of the infants are given in Table 1. The purpose and the procedures of the study were carefully explained to the parents and their agreement obtained. The experimental protocol was submitted to and accepted by the Ethical Committee of the University Hospital.

Assessment of growth. The following measurements were made during the first $8 \mathrm{wk}$ of life. Weight was measured daily to the nearest $5 \mathrm{~g}$. The weekly weight gain was calculated from the linear regression line of daily weight over time. This procedure was used to avoid imprecision in assessing weight gain due to day-to-day fluctuations in body weight. Weight gain at the time of each metabolic balance was assessed in the same way, the 3day balance being situated in the middle of the week considered.
Crown-to-heel length was measured weekly using a stadiometer. Increments in crown-to-heel length over the whole period, expressed as centimeters gained per week, were calculated from the regression line of weekly length over time. Head circumference was measured weekly with a cloth tape, and increment was similarly calculated. A cerebral ultrasound (performed in eight infants) showed that all infants but two, identified in Table 1 , were free from cerebral ventricular dilatation during the period of the study.

Diet. Four infants received their mother's milk: expressed breast milk was stored in a refrigerator and given to the infant over the following $48 \mathrm{~h}$. The others were fed an infant formula (Alprem MCT, Nestlé Ltd, Vevey, Switzerland) prepared from whole milk, whey, medium-chain triglycerides, lactalbumin, and vegetable oils. Details of the diet composition are given in Table 2. During the 3 -day balance, ${ }^{15} \mathrm{~N}$-glycine was diluted in deionized water, the resulting solution was sterilized through a $0.2 \mu$ filter (Nalgene, Sybron, NY), and then was added to the daily feeding. The preparation was thoroughly mixed, an aliquot taken for analysis and the remainder distributed in equal portions corre-

Table 2. Diet

\begin{tabular}{llccc}
\hline Infant & \multicolumn{1}{c}{ Type } & $\begin{array}{c}\text { Gross energy } \\
\text { intake } \\
\text { (kcal/kg-day) }\end{array}$ & $\begin{array}{c}\text { Protein } \\
\text { intake } \\
(\mathrm{g} / \mathrm{kg} \cdot \text { day })\end{array}$ & $\begin{array}{c}\text { Protein } \\
\text { energy } \\
(\%)\end{array}$ \\
\hline $\mathrm{MS}$ & $\mathrm{EBM}^{*}$ & 115 & 2.83 & 14 \\
$\mathrm{PG}$ & $\mathrm{EBM}^{\dagger}$ & 110 & 3.15 & 16 \\
$\mathrm{FM}_{1}$ & $\mathrm{EBM} \dagger$ & 112 & 3.21 & 16 \\
$\mathrm{FM}_{2}$ & $\mathrm{EBM} \dagger$ & 109 & 2.7 & 14 \\
$\mathrm{FM}_{3}$ & $\mathrm{EBM}^{\dagger}$ & 106 & 2.39 & 13 \\
$\mathrm{YR}_{1}$ & $\mathrm{EBM}^{*}$ & 132 & 3.18 & 14 \\
$\mathrm{YR}_{2}$ & Milk formula & 123 & 3.50 & 16 \\
$\mathrm{YR}_{3}$ & Milk formula $\ddagger$ & 105 & 2.85 & 15 \\
$\mathrm{LH}_{1}$ & Milk formula & 126 & 3.51 & 16 \\
$\mathrm{LH}_{2}$ & Milk formula & 107 & 2.97 & 16 \\
$\mathrm{CV}$ & Milk formula $\$$ & 86 & 1.61 & 10 \\
$\mathrm{CV}$ & Milk formula & 120 & 3.3 & 15 \\
$\mathrm{JNN}_{2}$ & Milk formula & 123 & 3.67 & 17 \\
$\mathrm{AG}$ & Milk formula & 109 & 2.95 & 15 \\
$\mathrm{MC}$ & Milk formula & 122 & 3.45 & 16 \\
$\mathrm{MD}$ & Milk formula & 122 & 3.3 & 15 \\
& & & & \\
$\mathrm{Mean} \pm$ & & 114 & 3.04 & 15 \\
$\mathrm{SD}$ & & 11 & 0.51 & 1.7 \\
\hline
\end{tabular}

* EBM = expressed breast milk from their own mother supplemented with other mothers' milk and $\dagger$ from their own mother only.

$\ddagger$ Received a formula ( $\mathrm{Nau}$ ) similar in protein and amino acid content. $\S$ With $10 \%$ glucose iv (i.e. $+21 \mathrm{kcal} / \mathrm{kg} \cdot$ day glucose energy).

Table 1. Clinical and growth characteristics

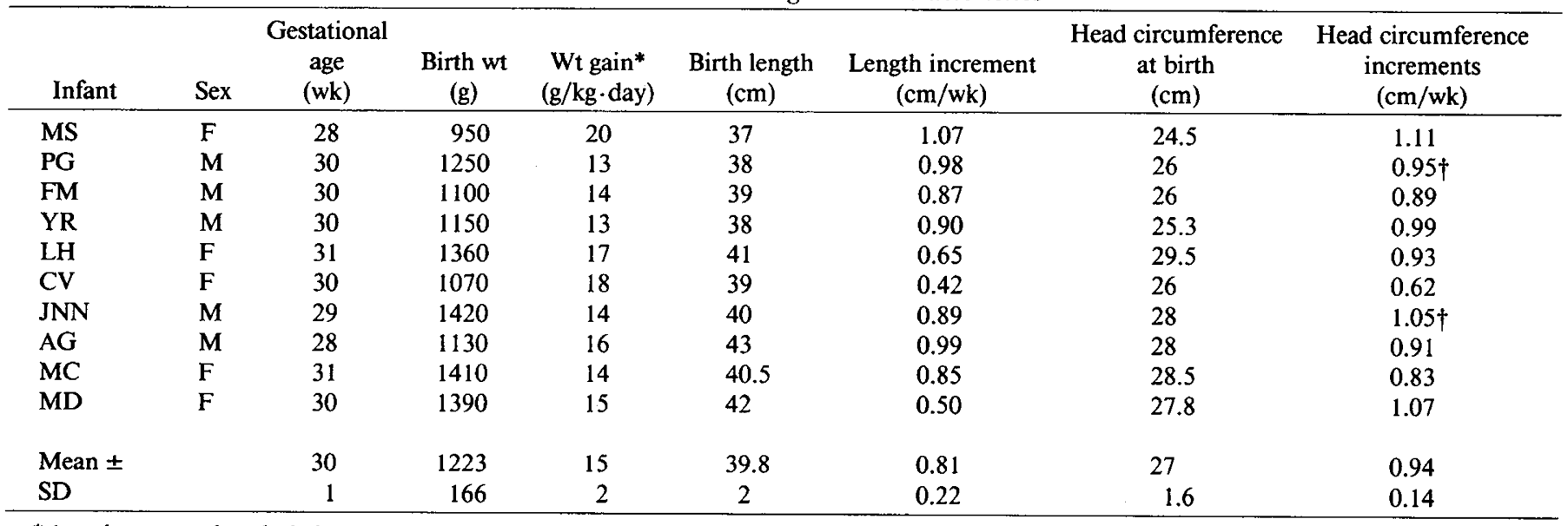

* 1st wk postnatal excluded.

† Ultrasound examination showed a moderate ventricular dilatation, which arrested spontaneously. 
sponding to the number of feeds. The amount of ${ }^{15} \mathrm{~N}$-glycine (95\% enrichment, CEA, Saclay, Gif-sur-Yvette, France) was calculated to provide about $5 \mathrm{mg}{ }^{15} \mathrm{~N}$ per kilogram per day. Every 24-h milk samples were analyzed for total nitrogen, ${ }^{15} \mathrm{~N}$, and energy content.

Metabolic balance techniques. Energy and nitrogen balances and whole body protein turnover studies were performed in each infant. The metabolic balance was initiated during the period of weight gain only, and as soon as the infant's respiratory status was stable. Furthermore the balance was performed after at least 3 days adaptation to the diet. The balance lasted between 60 to $72 \mathrm{~h}$ and energy expenditure was measured on the last $24 \mathrm{~h}$. The infants were nursed in incubators and were fed at 2 or 3 hourly intervals via a nasogastric tube. The volume ingested was measured using a $10-\mathrm{ml}$ syringe, and was recorded. Residual milk in the syringe was repeatedly measured and found to be much less than $0.5 \mathrm{ml}$ and was therefore neglected. When the nasogastric tube had to be changed, the residual milk it contained was subtracted from the amount given. Any regurgitation (subject AG) was collected to a cellulose paper placed between the infant and the bedding. Urine was collected by continuous aspiration from an adhesive plastic bag into a chilled cylinder (9) which was changed before each meal, i.e. every $2-3 \mathrm{~h}$. Using this technique, it was possible to study the infants in their usual prone position.

Analytical techniques. Stools were scrapped from the cellulose paper, homogenized with mortar and pestle, and lyophilized. Cellulose paper containing residual feces were dryed in a vacuum oven at $40^{\circ} \mathrm{C}$, then weighed, and the amount of dry residual feces were taken as the difference between the dry dirty and the dry clean papers. Analyses performed on five studies have shown little difference between the energy density of residual fecal content and that of the scraped feces. Therefore the total amount of nitrogen and fecal energy was calculated from the concentrations found in scraped homogenized feces. Nitrogen content of milk, stools, and urine were determined by the Kjeldahl method. Protein content of milk was calculated by multiplying total nitrogen by 6.38. Milk powder, samples of breast milk, and stools were burned in an adiabatic bomb calorimeter (PARR, model 1241, Moline, IL) to determine their gross energy content. Urinary energy loss was calculated from total urinary nitrogen $(\mathrm{g}) \times$ $7.9 \mathrm{kcal} / \mathrm{g} \mathrm{N}$ or $1.24 \mathrm{kcal} / \mathrm{g}$ oxidized protein (10). A constant percentage of each 2- or 3-h urine sample was taken to reconstitute a 24 -h urine pool. The latter was analyzed for total nitrogen, urea, ammonia, creatinine, and amino acids. Creatinine was determined by the Jaffe reaction in an Autoanalyzer (Technicon, Tarry Town, NY). In order to determine 3-methylhistidine excretion, urinary amino acids were analyzed by liquid phase chromatography (Biotronik, Frankfurt, BRD). Urea was titrated with urease in an automatic analyzer (Greiner, Langenthal, Switzerland) and ammonia by the Berthelot method (Roche Diagnostica, Basel, Switzerland). In each fractional urine sample, ammonia was separated by $1-\mathrm{h}$ aeration after urine alkalinization with $12.5 \mathrm{~N} \mathrm{NaOH}$, and trapped in $0.01 \mathrm{~N} \mathrm{HCl}$. Then the sample was further brought to a $\mathrm{pH}$ equal to 6.1, urease (Bittmann, 5 $\mathrm{U} / \mathrm{mg}$ ) was added and incubated for $2 \mathrm{~h}$ at $30^{\circ} \mathrm{C}$, and after realkalinization ammonia was again trapped in $0.01 \mathrm{~N} \mathrm{HCl}$. The ${ }^{15} \mathrm{~N}$ enrichment of urea and ammonia was subsequently determined automatically by emission spectrometry (Isonitromat 5201 VEB, Statron, DDR) from the ammonium chloride salt. The ${ }^{15} \mathrm{~N}$ enrichment in stools was determined in the same way from ammonium chloride resulting from Kjeldahl digestion. The net ${ }^{15} \mathrm{~N}$ enrichment was calculated as the difference between the total ${ }^{15} \mathrm{~N}$ enrichment minus the natural abundance of ${ }^{15} \mathrm{~N}$, determined to be 0.37 atoms \%.

Measurement of energy expenditure. Total daily energy expenditure was measured by open circuit calorimetry as previously described (1). A tight perspex box containing the whole infant was placed inside the incubator. During the measurement, the infant's thermoneutrality was continuously monitored via a ther- mistance placed on the abdominal skin. Activity was checked every minute using Brück's activity scale (11). The latter varies from a -4 level (eyes closed, no movement) to $a+5$ level (crying, eyes open or closed). Total energy expenditure was taken as the mean of the whole period of measurement whereas energy expenditure in resting state was assessed when the child had an activity score of -4 or -3 (eyes closed, facial movements). The measurements were taken after completion of the last meal over a period of 1 to $3 \mathrm{~h}$ (mean $1 \mathrm{~h} 35 \mathrm{~min}$ ). Our previous study (1) has shown that the pattern of energy expenditure in very low birth weight infants fed at constant intermittent intervals is stable (range of intraindividual coefficient of variation $=3.5-6.6 \%$ ) so that the measurements may be extrapolated to $24 \mathrm{~h}$ with relatively little error.

Composition of weight gain. Assuming that energy retained is mainly stored in the form of lipids and proteins and knowing that the gross energy content of protein is $5.6 \mathrm{kcal} / \mathrm{g}$, an estimation of the composition of weight gain was obtained as follows:

$$
\text { energy stored in lipids }=\underset{\times 5.6)}{\text { energy balance }}-(\text { protein retained }
$$

where energy balance and energy stored are in $\mathrm{kcal} / \mathrm{kg} \cdot \mathrm{day}$ and protein retained in $\mathrm{g} / \mathrm{kg}$. day.

Knowing that the energy density of lipids is $9.3 \mathrm{kcal} / \mathrm{g}$ an estimate of the quantity of lipids stored $(\mathrm{g} / \mathrm{kg} \cdot \mathrm{d})$ was obtained as follows:

$$
\text { quantity of lipids stored }=\frac{\text { energy stored in lipids }}{9.3}
$$

Protein turnover. Whole-body protein synthesis and breakdown were estimated by the method of Picou and Taylor-Roberts (12), as subsequently modified by Steffee $e t$ al. (13) using ${ }^{15} \mathrm{~N}$-glycine.

The assumptions involved with this method have been discussed previously $(12,14)$. Three methods were used to estimate the enrichment in ${ }^{15} \mathrm{~N}$ and products at plateau: 1) simple visual inspection, 2) exponential curve fit, and 3) polynomial curve fit.

Using visual inspection, the starting point of the plateau was taken as the first value which is followed at some time later by a lower one (14) and the plateau was calculated from the arithmetic means of this point and the following ones. The second approach assumes that the time course of the labeling follows a single exponential of the form $y=y_{0}\left(1-e^{-\lambda t}\right)(13)$. The third approach assumes that the response follows a second degree polynomial regression and the plateau is defined when the function attains its maximum.

Muscle protein breakdown. Muscle protein breakdown was calculated from the measurement of 24-h urinary excretion of 3MHis, using the values of Lunyong and Friedman (15) for the 3-MHis content of skeletal muscle in premature infants between 26 and 38 wk gestation.

$$
\text { muscle protein breakdown }=\frac{3-\mathrm{MHis} \text { excretion }}{\text { skeletal muscle 3-MHis content }}
$$

Lunyong and Friedman (15) found a 3MHis content of 2.64 $\mu \mathrm{mol} / \mathrm{g}$ protein at $26-32 \mathrm{wk}$ and of $3.28 \mu \mathrm{mol} / \mathrm{g}$ protein at 37 $38 \mathrm{wk}$ of gestation. Assuming that the increment in 3-MHis content is essentially linear, the average change in 3-MHis per week gestation was calculated from a linear interpolation between these values.

\section{RESULTS}

Composition and apparent digestibility of the diet. Details of the diet composition and of the energy and protein digestibility are given in Tables 2 and 3, respectively. The protein energy to total energy ratio averaged $15 \%$ and was not different in infants receiving breast milk compared with those receiving formula milk. Mean gross energy intake was $114 \mathrm{kcal} / \mathrm{kg}$. day and the apparent energy digestibility was $88 \%$. Mean nitrogen intake was 
Table 3. Apparent digestible energy and protein

\begin{tabular}{|c|c|c|c|c|c|c|}
\hline Infant & $\begin{array}{c}\text { Gross energy } \\
\text { intake } \\
\text { (kcal/kg } \cdot \text { day) }\end{array}$ & $\begin{array}{c}\text { Fecal energy } \\
\text { (kcal/kg·day) }\end{array}$ & $\begin{array}{l}\text { Apparent energy } \\
\text { digestibility } \\
(\%)\end{array}$ & $\begin{array}{c}\text { Gross } N \text { intake } \\
(\mathrm{g} / \mathrm{kg} \cdot \text { day })\end{array}$ & $\begin{array}{c}\text { Fecal N } \\
(\mathrm{g} / \mathrm{kg} \cdot \text { day })\end{array}$ & $\begin{array}{c}\text { Apparent } \\
\mathrm{N} \\
\text { digestibility } \\
(\%)\end{array}$ \\
\hline MS & 115 & 26 & 77 & 0.444 & 0.140 & 69 \\
\hline PG & 110 & & & 0.494 & & \\
\hline $\mathrm{FM}_{1}$ & 112 & 28 & 75 & 0.503 & 0.058 & 89 \\
\hline $\mathrm{FM}_{2}$ & 109 & & & 0.424 & & \\
\hline $\mathrm{FM}_{3}$ & 106 & 11 & 90 & 0.375 & 0.043 & 89 \\
\hline $\mathrm{YR}_{1}$ & 132 & 26 & 80 & 0.498 & 0.051 & 90 \\
\hline $\mathrm{YR}_{2}$ & 123 & 17 & 87 & 0.548 & 0.042 & 92 \\
\hline $\mathrm{YR}_{3}$ & 105 & & & 0.447 & & \\
\hline $\mathrm{LH}_{1}$ & 126 & 19 & 85 & 0.551 & 0.061 & 89 \\
\hline $\mathrm{LH}_{2}$ & 107 & 5 & 95 & 0.466 & 0.038 & 92 \\
\hline $\mathrm{CV}_{1}$ & 86 & 2 & 96 & 0.253 & 0.011 & 96 \\
\hline $\mathrm{CV}_{2}$ & 120 & 11 & 91 & 0.520 & 0.050 & 90 \\
\hline JNN & 123 & 13 & 90 & 0.576 & 0.070 & 88 \\
\hline AG & 109 & 8 & 93 & 0.463 & 0.052 & 89 \\
\hline MC & 122 & 4 & 96 & 0.540 & 0.025 & 95 \\
\hline MD & 122 & & & 0.521 & & \\
\hline Mean \pm & 114 & 14 & 88 & 0.476 & 0.053 & 89 \\
\hline SD & 11.1 & 9.0 & 7 & 0.080 & 0.032 & 7 \\
\hline
\end{tabular}

Table 4. Energy and nitrogen balance

\begin{tabular}{|c|c|c|c|c|c|c|c|c|c|}
\hline Infant & $\begin{array}{c}\text { Age } \\
\text { at study } \\
\text { days } \\
\end{array}$ & $\begin{array}{c}\text { Wt at study } \\
\text { (g) }\end{array}$ & $\begin{array}{c}\text { Wt gain } \\
(\mathrm{g} / \mathrm{kg} \cdot \text { day })\end{array}$ & $\begin{array}{c}\text { Metabolizable } \\
\text { energy* } \\
\text { (kcal/kg·day) }\end{array}$ & $\begin{array}{c}\text { Energy } \\
\text { expenditure } \\
(\mathrm{kcal} / \mathrm{kg} \cdot \text { day }) \\
\end{array}$ & $\begin{array}{c}\text { Energy } \\
\text { balance } \\
(\mathrm{kcal} / \mathrm{kg} \cdot \text { day }) \\
\end{array}$ & $\begin{array}{c}\mathrm{N} \text { absorbed } \\
\text { (g/kg.day) }\end{array}$ & $\begin{array}{l}\text { Urinary } \mathrm{N} \\
(\mathrm{g} / \mathrm{kg} \cdot \\
\text { day) }\end{array}$ & $\begin{array}{l}N \text { balance* } \\
\text { (g/kg.day) }\end{array}$ \\
\hline MS & 26 & 1310 & 15.7 & 88 & 55 & 33 & 0.304 & 0.111 & 0.193 \\
\hline PG & 6 & 1110 & 12.8 & $96 \dagger$ & & & $0.440 \ddagger$ & 0.164 & 0.276 \\
\hline $\mathrm{FM}_{1}$ & 11 & 1080 & 9.3 & 83 & 58 & 25 & 0.460 & 0.093 & 0.352 \\
\hline $\mathrm{FM}_{2}$ & 24 & 1340 & 12.3 & $96 \dagger$ & 52 & 44 & $0.377 \ddagger$ & 0.090 & 0.287 \\
\hline $\mathrm{FM}_{3}$ & 46 & 1820 & 14.7 & 95 & 59 & 36 & 0.332 & 0.091 & 0.241 \\
\hline $\mathbf{Y R}_{2}$ & 40 & 1720 & 17.0 & 105 & 59 & 46 & 0.506 & 0.194 & 0.312 \\
\hline $\mathbf{Y R}_{3}$ & 62 & 2390 & 16.6 & $92 \dagger$ & 61 & 31 & $0.398 \ddagger$ & 0.106 & 0.292 \\
\hline $\mathrm{LH}_{1}$ & 8 & 1240 & 18.4 & 107 & 70 & 37 & 0.490 & 0.116 & 0.374 \\
\hline $\mathrm{LH}_{2}$ & 30 & 1810 & 14.4 & 101 & 61 & 40 & 0.428 & 0.186 & 0.242 \\
\hline $\mathrm{CV}_{1}$ & 4 & 1020 & 7.2 & 83 & 43 & 40 & 0.242 & 0.125 & 0.117 \\
\hline $\mathrm{CV}_{2}$ & 15 & 1200 & 20.8 & 107 & 62 & 45 & 0.470 & 0.164 & 0.306 \\
\hline JNN & 39 & 2140 & 22.3 & 109 & 68 & 41 & 0.506 & 0.174 & 0.332 \\
\hline MD & 20 & 1430 & 19.7 & $107 \dagger$ & & & $0.464 \ddagger$ & 0.090 & 0.374 \\
\hline Mean \pm & 26 & 1548 & 15 & 99 & 58 & 41 & 0.424 & 0.137 & 0.287 \\
\hline SD & 17 & 108 & 4 & 9.6 & 6.8 & 9.3 & 0.078 & 0.050 & 0.068 \\
\hline
\end{tabular}

* Metabolizable energy $=$ gross energy intake $-($ fecal energy + urinary energy); $N$ Balance $=$ gross $\mathrm{N}$ intake $-($ fecal $\mathrm{N}+$ urinary $\mathrm{N})=\mathrm{N}$ absorbed - urinary $\mathrm{N}$.

$\dagger$ Assuming $12 \%$ energy loss in feces.

$\ddagger$ Assuming $11 \%$ loss in feces.

$0.476 \mathrm{~g} / \mathrm{kg}$. day and the apparent nitrogen digestibility was $89 \%$. Energy balance (Table 4). Metabolizable energy was calculated from gross energy of the diet minus fecal and urinary energy losses. The mean metabolizable energy was $99 \mathrm{kcal} / \mathrm{kg} \cdot$ day, giving a mean positive energy balance of $41 \mathrm{kcal} / \mathrm{kg}$. day. No relationship was found between gross energy intake and energy balance, whereas a significant positive relationship $(r=0.75, p$ $<0.01$ ) was found between metabolizable energy intake and energy balance (Fig. 1). The slope of the regression indicates that approximately $70 \%$ of metabolizable energy given above maintenance requirement is stored and the remaining $30 \%$ is oxidized. The intercept at zero energy balance (not shown in Fig. 1) indicates that $40 \mathrm{kcal} / \mathrm{kg}$. day of metabolizable energy are required to maintain energy balance.
Mean resting energy expenditure ( $\mathrm{y}$, in $\mathrm{kcal} / \mathrm{kg} \cdot$ day) augmented with increasing weight gain $(x$, in $\mathrm{g} / \mathrm{kg}$.day) and the regression analysis equation is $\mathrm{y}=39.1+1.2 \times(r=0.81 ; n=$ $14 ; p<0.001)$. At zero weight gain resting energy expenditure is approximately $40 \mathrm{kcal} / \mathrm{kg}$. day. The slope of the regression line shows that $1.2 \mathrm{kcal}$ are expended for each additional gram of weight gain; thus for infants growing at a rate of $15 \mathrm{~g} / \mathrm{kg} \cdot$ day and having a resting energy expenditure of $57 \mathrm{kcal} / \mathrm{kg}$. day, the cost of new tissue synthesis is $18 \mathrm{kcal}$ or $32 \%$ of their daily resting energy expenditure.

Nitrogen balance (Table 4). Since obligatory nitrogen losses from skin and sweat were not measured, "crude" nitrogen balance only is presented. Urinary nitrogen loss represented about one-third of nitrogen apparently absorbed, and the average nitro- 
gen balance was $0.287 \mathrm{~g} / \mathrm{kg}$. day. Figure 2 shows the positive, statistically significant relationship $(r=0.78 ; p<0.001)$ between nitrogen intake and nitrogen balance. The linear regression line extrapolated to zero nitrogen intake (not shown in Fig. 2) gives a value of $-0.032 \mathrm{~g} / \mathrm{kg}$. day which is an estimate of apparent

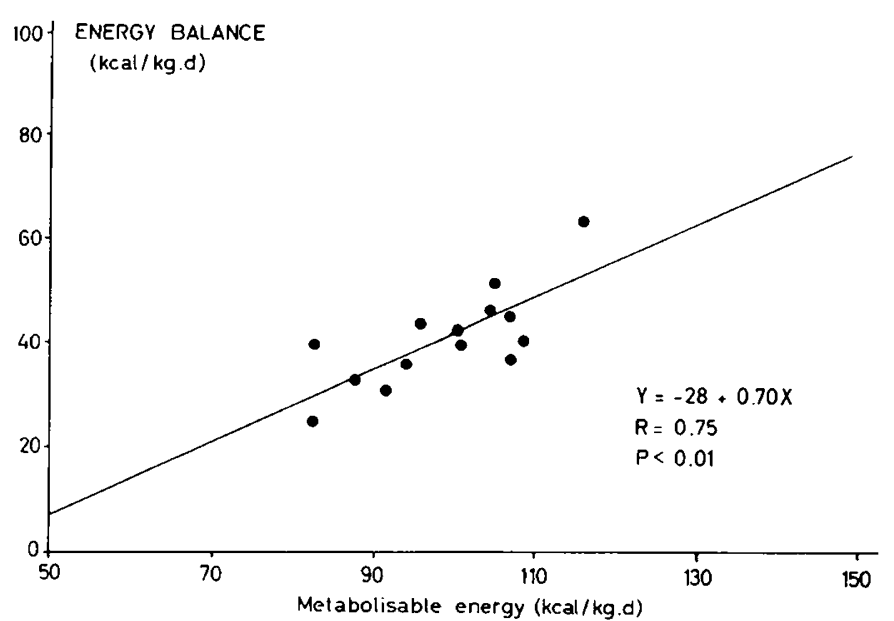

Fig. 1. Relationship between metabolizable energy intake and energy balance.

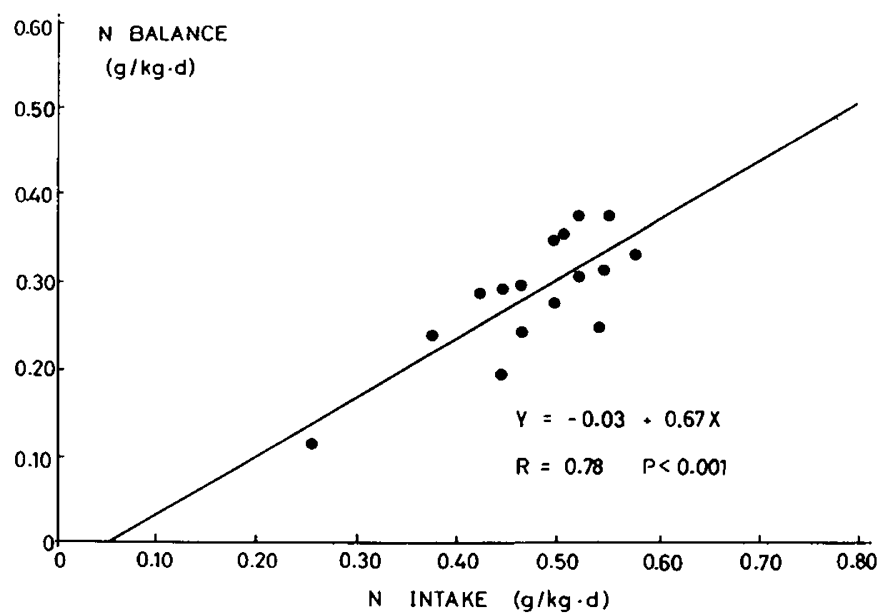

Fig. 2. Relationship between nitrogen intake and nitrogen balance. obligatory nitrogen losses. At zero $\mathrm{N}$ balance $(\mathrm{y}=0)$, an estimate of $0.048 \mathrm{~g} / \mathrm{kg}$. day was found for the nitrogen intake required to maintain constant body $\mathrm{N}$. The slope of the regression line, i.e. the coefficient of net protein utilization, was 0.67 .

Weight gain and estimate of the composition of weight gain (Table 5). The average weight gain during the study was $15 \mathrm{~g} /$ $\mathrm{kg}$.day. The mean lipid gain calculated from energy and $\mathrm{N}$ balances was $3.4 \mathrm{~g} / \mathrm{kg}$. day, thus giving a mean fat free mass gain of $11.6 \mathrm{~g} / \mathrm{kg} \cdot$ day; i.e. $75 \%$ of weight gain. The mean ratio of protein gain to fat free mass gain was $17 \%$.

Total body protein turnover. Urinary ammonia showed ${ }^{15} \mathrm{~N}$ enrichment in all studies, but in five studies urea failed to be enriched at all. Using the visual approach, ammonia and urea plateau were reached by 30 to $54 \mathrm{~h}$ (mean $36 \mathrm{~h}$ for ammonia and $41 \mathrm{~h}$ for urea, Fig. 3). Nevertheless in half of the cases a pseudo-plateau was observed with ammonia before $30 \mathrm{~h}$. No matter which method was used to assess the plateau, protein synthesis obtained from ammonia enrichment was significantly lower $(p<0.001)$ than that calculated from urea enrichment.

Mean protein synthesis $( \pm \mathrm{SD})$ calculated by these three methods is:

1) Using ammonia as end-product: visual method : $6.24 \pm$ $1.61 \mathrm{~g} / \mathrm{kg} \cdot$ day; exponential method : $6.03 \pm 1.70 \mathrm{~g} / \mathrm{kg} \cdot$ day; polynomial method : $5.83 \pm 1.51 \mathrm{~g} / \mathrm{kg} \cdot$ day. No significant

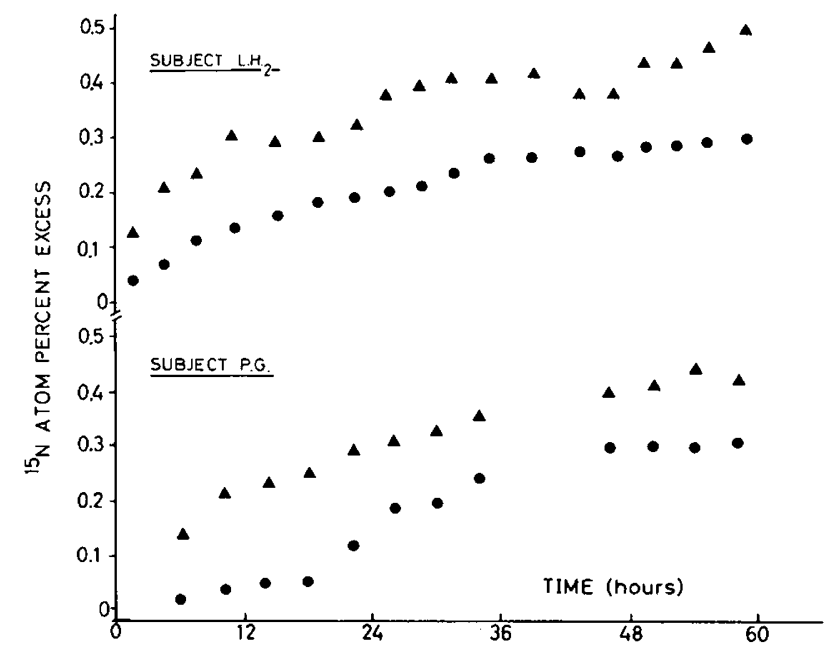

Fig. 3. Time-course of ${ }^{15} \mathrm{~N}$-enrichment in urea (O) and ammonia (A) following administration of ${ }^{15} \mathrm{~N}$-glycine in two infants.

Table 5. Composition of wt gain

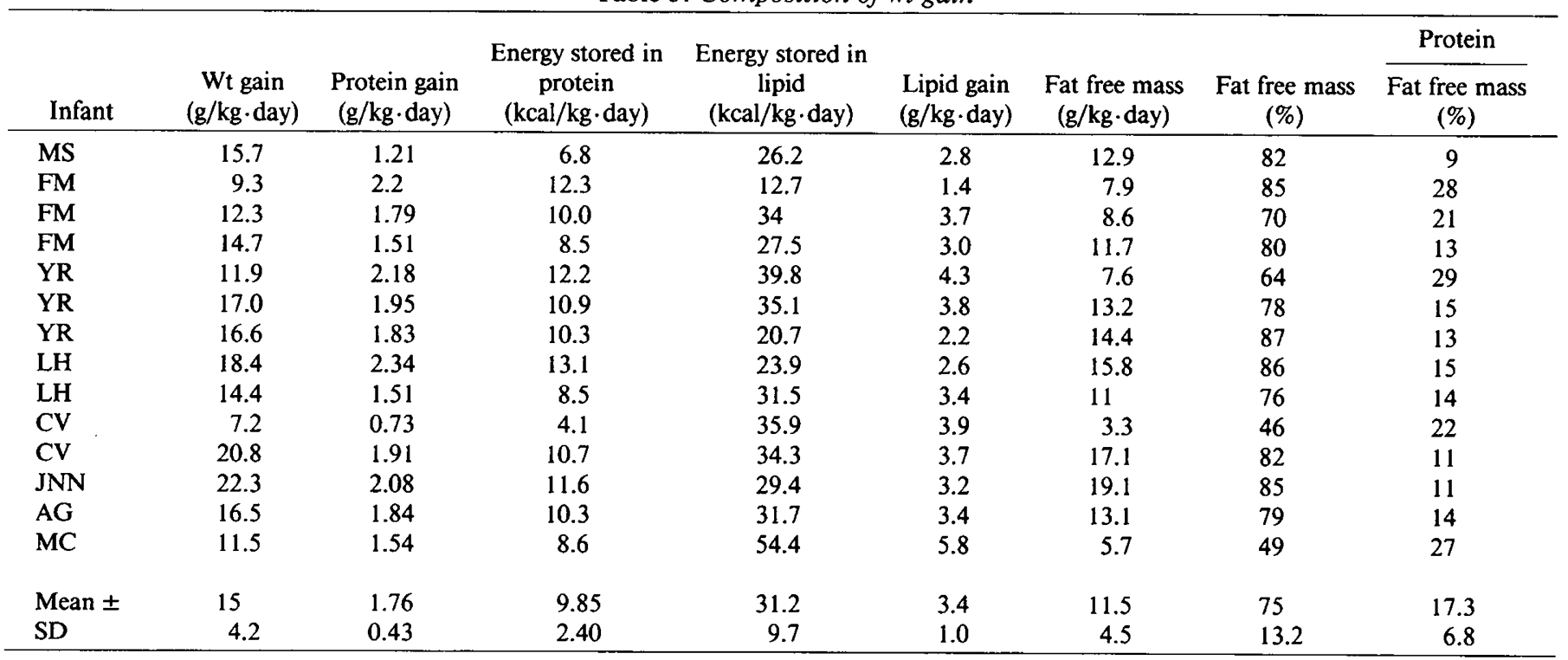


difference in protein synthesis was found among the exponential, the visual, or polynomial methods. However, the polynomial versus the visual method gave significantly different results $(p<$ $0.001)$. 2) Using urea as end-product: visual method : : $12.6 \pm$ $4.86 \mathrm{~g} / \mathrm{kg} \cdot$ day; exponential method : : $8.63 \pm 2.32 \mathrm{~g} / \mathrm{kg} \cdot$ day; polynomial method : : $11.2 \pm 3.55 \mathrm{~g} / \mathrm{kg} \cdot$ day. There was a significant difference between the exponential versus the polynomial method $(p<0.005)$, as well as between the exponential and polynomial versus the visual $(p<0.001$ and $<0.05$, respectively).

However, there was a direct relationship between protein synthesis calculated from visual and exponential method $(p<$ $0.001)$, as well as between the visual and polynomial method ( $p$ $<0.001$ ). As suggested by Waterlow et al. (14), we used the visual method as reference and compared the two other methods against it: the regression line that was the nearest to the identity line (i.e. slope $=1$ ) and had the highest correlation coefficient was the polynomial method. The equations giving protein synthesis calculated by the visual approach (y) from that calculated by thepolynomial approach $(\mathrm{x})$ are: Urea: $\mathrm{y}=0.18+1.065 \times$; $r=$ $0.962 ; n=10$. Ammonia: $\mathrm{y}=0.008+1.077 \times ; r=0.976 ; n=$ 14. Therefore for reasons outlined in the discussion, protein synthesis and breakdown presented in this report are based on the polynomial method (Table 6).

Protein synthesis calculated using any of the end-products was significantly correlated with protein gain. Figure 4 gives the linear correlation between protein synthesis calculated from enrichment in urea and protein gain. The slope of the regression indicates that for each gram of protein gained there is an increase in protein synthesis of about $5 \mathrm{~g}$ (accompanied by a simultaneous breakdown of $4 \mathrm{~g}$ ).

Relationship between energy expenditure, protein gain, and protein synthesis. Figure 5 shows the relationship between resting energy expenditure and net protein gain $(r=0.65, p<0.01)$. From the slope of the regression line one can infer that for each gram of protein gain, there is a simultaneous increase of approximately $10 \mathrm{kcal}$ of energy expenditure. The intercept at zero protein gain indicates that about $40 \mathrm{kcal} / \mathrm{kg}$. day are expended when nitrogen balance is equilibrated and this corresponds to the estimate of metabolizable energy which was necessary to maintain zero energy balance (Fig. 1). There was a positive relationship between resting energy expenditure and protein synthesis but the relationship was on the borderline of statistical significance $(r=0.56 ; n=9 ; p<0.07)$, so that the energy cost of protein synthesis cannot be calculated directly. However, as 5 $\mathrm{g}$ of protein are synthesized for each gram of protein gain (Fig. 4), with an extra energy expenditure of $10 \mathrm{kcal}$, an indirect estimate of the cost of protein synthesis would be $2 \mathrm{kcal} / \mathrm{g}$ synthesized.

Muscle protein breakdown (Table 7). Mean muscle protein breakdown was found to be about $1 \mathrm{~g} / \mathrm{kg}$. day, a value representing $13 \%$ of total protein breakdown.

\section{DISCUSSION}

Clinical course and growth. The infants grew without clinical complications and their average weight gain, length, and head

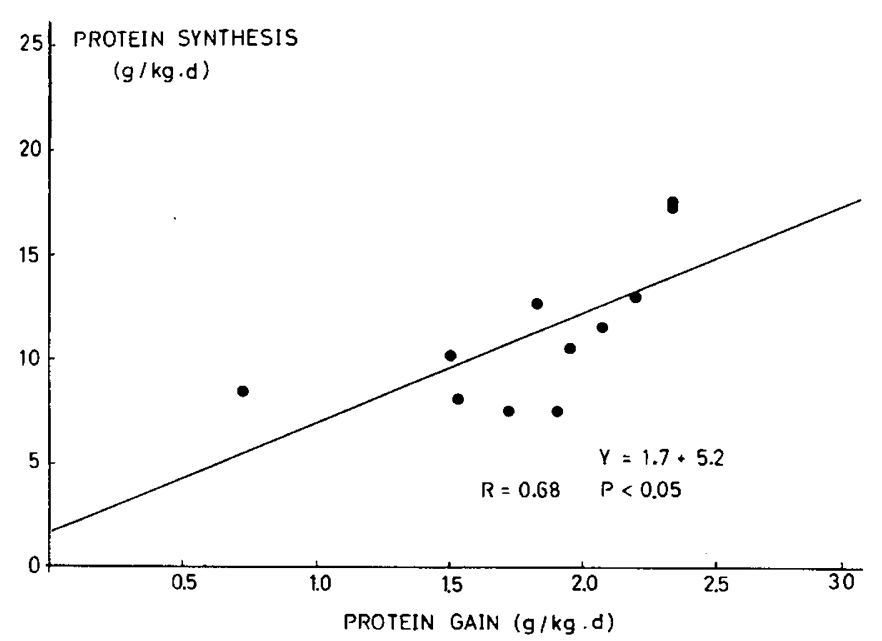

Fig. 4. Relationship between protein gain and protein synthesis.

Table 6. Total body nitrogen turnover

\begin{tabular}{|c|c|c|c|c|c|c|c|c|c|c|}
\hline \multicolumn{6}{|c|}{ Urea } & \multicolumn{5}{|c|}{$\mathrm{NH}_{3}$} \\
\hline Infant & $\begin{array}{c}\text { N flux } \\
\dot{Q} \\
\text { (g/kg·day) } \\
\end{array}$ & $\begin{array}{c}\begin{array}{c}\text { Protein } \\
\text { synthesis* } \\
\text { (g/kg·day) }\end{array} \\
\end{array}$ & $\begin{array}{c}\text { Protein } \\
\text { breakdown* } \\
(\mathrm{g} / \mathrm{kg} \cdot \text { day })\end{array}$ & $\begin{array}{l}\dot{S} / \dot{Q} \\
(\%)\end{array}$ & $\begin{array}{l}\dot{\mathrm{B}} / \mathrm{Q} \\
(\%) \\
\end{array}$ & $\begin{array}{c}\mathrm{N} \text { flux } \\
\dot{Q} \\
\text { (g/kg·day) }\end{array}$ & $\begin{array}{c}\text { Protein } \\
\text { synthesis* } \\
\text { (g/kg·day) }\end{array}$ & $\begin{array}{c}\text { Protein } \\
\text { breakdown* } \\
\text { (g/kg.day) }\end{array}$ & $\begin{array}{l}\dot{S} / Q \dot{Q} \\
(\%)\end{array}$ & $\begin{array}{l}\dot{\mathrm{B}} / \dot{\mathrm{Q}} \\
(\%)\end{array}$ \\
\hline MS & $\dagger$ & $\dagger$ & $\dagger$ & $\dagger$ & $\dagger$ & 0.80 & 4.3 & 3.1 & 86 & 62 \\
\hline PG & 1.35 & 7.4 & 5.7 & 88 & 68 & 1.02 & 5.3 & 3.6 & 84 & 57 \\
\hline $\mathrm{FM}_{1}$ & 2.16 & 12.9 & 10.7 & 96 & 79 & 1.08 & 6.2 & 4.0 & 91 & 59 \\
\hline $\mathrm{FM}_{2}$ & $\dagger$ & $\dagger$ & $\dagger$ & $\dagger$ & $\dagger$ & 1.56 & 9.2 & 7.4 & 94 & 76 \\
\hline $\mathrm{FM}_{3}$ & $\dagger$ & $\dagger$ & $\dagger$ & $\dagger$ & $\dagger$ & 0.69 & 3.8 & 2.3 & 87 & 52 \\
\hline $\mathrm{YR}_{1}$ & $\dagger$ & $\dagger$ & $\dagger$ & $\dagger$ & $\dagger$ & 1.30 & 7.5 & 5.3 & 92 & 66 \\
\hline $\mathrm{YR}_{2}$ & 1.86 & 10.4 & 8.4 & 90 & 73 & 1.06 & 5.4 & 3.5 & 82 & 52 \\
\hline $\mathrm{YR}_{3}$ & $\dagger$ & $\dagger$ & $\dagger$ & $\dagger$ & $\dagger$ & 0.73 & 3.9 & 2.1 & 85 & 45 \\
\hline $\mathrm{LH}_{1}$ & 2.91 & 17.4 & 15.1 & 96 & 83 & 1.26 & 7.1 & 4.8 & 91 & 61 \\
\hline $\mathrm{LH}_{2}$ & 1.81 & 10.2 & 8.7 & 90 & 76 & 1.17 & 6.1 & 4.6 & 84 & 63 \\
\hline $\mathrm{CV}_{1}$ & 1.47 & 8.4 & 7.7 & 92 & 84 & 0.78 & 4.1 & 3.4 & 84 & 68 \\
\hline $\mathrm{CV}_{2}$ & 1.36 & 7.4 & 5.5 & 88 & 65 & 1.04 & 5.5 & 3.6 & 84 & 55 \\
\hline JNN & 2.01 & 11.5 & 9.4 & 91 & 75 & 1.20 & 6.4 & 4.3 & 85 & 58 \\
\hline AG & 2.15 & 12.7 & 10.9 & 95 & 81 & 1.01 & 5.6 & 3.7 & 88 & 59 \\
\hline $\mathrm{MC}$ & 1.58 & 8.2 & 6.6 & 83 & 69 & $\ddagger$ & $\ddagger$ & $\ddagger$ & $\ddagger$ & $\ddagger$ \\
\hline MD & 2.83 & 17.1 & 14.8 & 97 & 84 & 1.25 & 7.2 & 4.9 & 93 & 68 \\
\hline Mean \pm & 1.95 & 11.2 & 9.4 & 91 & 76 & 1.06 & 5.8 & 4.0 & 87 & 60 \\
\hline SD & 0.54 & 3.5 & 3.3 & 4 & 7 & 0.24 & 1.5 & 1.3 & 4 & 8 \\
\hline
\end{tabular}

$*(\mathrm{~N} \times 6.25)$.

$\uparrow$ No enrichment in urea.

$\ddagger$ No data. 
circumference were the same as these found by Largo et al. (16) and other authors $(3,17)$ for very low birth weight infants receiving a similar type of diet.

Digestibility of the diet. Throughout the study, all infants tolerated their diet well. The mean apparent energy and nitrogen digestibility (Table 3 ) are both similar to that obtained in very low birth weight infants fed their own mother's milk or an adapted infant formula $(18,19)$. However, the apparent digestibility appears to be greater than that observed in premature infants fed pooled breast milk (18) or given a very high amount of energy intake (20). In the present study no attempt was made to compare breast-fed and formula-fed infants because of the small number of infants in the breast-fed group, and because some infants were repeatedly studied in each group.

Energy balance. The fact that energy balance correlated well with metabolizable energy, but not with gross energy intake, demonstrates that differences in energy digestibility play an important role in the energy balance of these infants. Seventy percent of metabolizable energy given above maintenance requirement is stored, a value nearly as high as that calculated

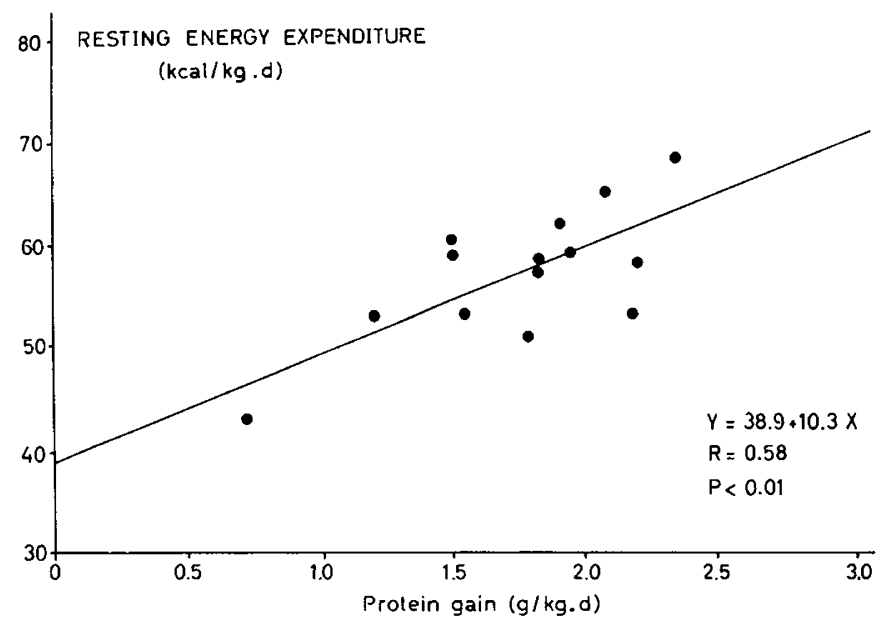

Fig. 5. Relationship between resting energy expenditure and protein gain. from the results of Spady et al. (21) in children recovering from malnutrition (80\%). At zero energy balance, the intercept of the regression line shows that maintenance energy is about $40 \mathrm{kcal} /$ $\mathrm{kg}$.day; this estimate is similar to the estimation of energy expenditure at zero weight gain (the extrapolation of the regression line between weight gain and energy expenditure) and to the energy expenditure of nongrowing very low birth weight infants previously studied under similar experimental conditions (1). It does not differ substantially from the amount of metabolizable energy which permits term infants to maintain an equilibrated energy balance (22).

Nitrogen balance. The relationship between nitrogen intake and nitrogen balance found in the present study (Fig. 2) indicates a maintenance nitrogen requirement of $48 \mathrm{mg} / \mathrm{kg}$. day. However, this estimate does not include the insensible nitrogen losses that were not measured in the present study. Pencharz et al. (6) calculated that insensible nitrogen loss is $15.2 \mathrm{mg} / \mathrm{kg} \cdot$ day in premature infants. Using the value given by these investigators, the corrected maintenance nitrogen requirement was found to be $70 \mathrm{mg} / \mathrm{kg}$. day, a value close to that found by Jackson et al. (5). The net efficiency of protein utilization $(67 \%)$ is also similar to those reported by these authors. The infants' birth weights were between the 10th and the 50th percentile of Lubchenko standards (23) and the daily nitrogen retention of infants receiving around $500 \mathrm{mg} \mathrm{N} / \mathrm{kg}$. day was close to the nitrogen retention calculated by Jackson et al. (5) for fetuses of the same gestational age growing along the 50 th percentile. According to Figure 2 , a daily intake of $500-550 \mathrm{mg} / \mathrm{kg}$. day of nitrogen $(3.2-3.5 \mathrm{~g}$ of protein) would be sufficient to allow nitrogen retention at the same rate as that occurring in utero.

Composition of weight gain. Data of Widdowson (24) indicate that fetuses of the same weight and gestational age as in the present study would have the following composition of weight gain: fat, $18 \%$; protein, $13 \%$; fat free mass, $82 \%$; and the ratio of protein to fat free mass would be about $16 \%$. The fat free mass gain of our infants, expressed as a fraction of weight gain, was $75 \%$ (range $46-87 \%$ ), thus slightly less than that occurring in utero. The mean ratio of protein to fat free mass of $16 \%$ (range $9-27 \%$ ) found in the present study is similar to that given by Widdowson (24). The large variability in the amount of fat free mass and of the percentage of protein in fat free mass explain

Table 7. Skeletal muscle breakdown

\begin{tabular}{|c|c|c|c|c|c|}
\hline Infant & $\begin{array}{c}\text { 3-mHis } \\
\text { excretion } \\
(\mu \mathrm{mol} / \mathrm{kg} \cdot \text { day })\end{array}$ & $\begin{array}{c}\text { Muscle protein } \\
\text { breakdown } \\
\text { (g/kg.day) }\end{array}$ & $\begin{array}{c}\text { Total protein* } \\
\text { breakdown } \\
(\mathrm{g} / \mathrm{kg} \cdot \text { day) }\end{array}$ & $\begin{array}{c}\begin{array}{c}\text { Muscle protein } \\
\text { breakdown }\end{array} \\
\begin{array}{c}\text { Total protein breakdown } \\
(\%)\end{array}\end{array}$ & $\begin{array}{c}\text { Creatinine excretion } \\
(\mathrm{mg} / \mathrm{kg} \cdot \text { day })\end{array}$ \\
\hline MS & 3.1 & 1.1 & $*$ & $*$ & 10.33 \\
\hline PG & 3.4 & 1.3 & 5.7 & 21 & 8.94 \\
\hline $\mathrm{FM}_{1}$ & 2.3 & 0.8 & 10.7 & 7 & 10.65 \\
\hline $\mathrm{FM}_{2}$ & 2.9 & 1.0 & * & * & 10.61 \\
\hline $\mathrm{FM}_{3}$ & 2.9 & 0.9 & $*$ & $*$ & 13.00 \\
\hline $\mathrm{YR}_{1}$ & 2.4 & 0.8 & $*$ & * & 9.53 \\
\hline $\mathrm{YR}_{2}$ & 2.7 & 0.9 & 8.4 & 10 & 11.13 \\
\hline $\mathrm{YR}_{3}$ & 1.8 & 0.6 & $*$ & * & 11.05 \\
\hline $\mathrm{LH}_{1}$ & 2.4 & 0.9 & 15.1 & 6 & 10.12 \\
\hline $\mathrm{LH}_{2}$ & 3.6 & 1.2 & 8.7 & 13 & 12.76 \\
\hline $\mathrm{CV}_{1}$ & 4.3 & 1.6 & 7.7 & 20 & 13.16 \\
\hline $\mathrm{CV}_{2}$ & 3.3 & 1.1 & 5.5 & 21 & 14.67 \\
\hline JNN & 3.4 & 1.1 & 9.4 & 12 & 9.0 \\
\hline AG & 2.7 & 0.9 & 10.9 & 8 & 10.36 \\
\hline $\mathrm{MC}$ & 2.4 & 0.8 & 6.6 & 12 & 11.79 \\
\hline MD & 2.9 & 1.0 & 14.8 & 7 & 16.36 \\
\hline Mean \pm & 2.9 & 1.0 & 9.4 & 12 & 11.47 \\
\hline SD & 0.61 & 0.24 & 3.3 & 6 & 2.06 \\
\hline
\end{tabular}

* $(\mathrm{N} \times 6.25)$. 
why it is fallacious to attempt to predict protein (or lean tissue) gain simply from weight gain in these infants.

The infants of the present study had a smaller fat retention than that found by Reichman et al. (19). The infants of the latter study were gaining $5.4 \mathrm{~g} / \mathrm{kg}$. day of fat, or $32 \%$ of their daily weight gain, versus $3.4 \mathrm{~g} / \mathrm{kg} \cdot$ day, or $25 \%$ in the present study, but they were also receiving a higher metabolizable energy: 130 versus $99 \mathrm{kcal} / \mathrm{kg}$. day in the present study. Further the method used to assess fat retention was not the same. However, the fat retention of both studies still appears to be greater than that occurring in the fetus, and the possible reasons and consequences for this have been discussed previously (19).

Protein turnover. Some of the difficulties encountered when assessing the plateau of either urea or ammonia enrichment are illustrated by the examples shown in Figure 3 . Using visual inspection, it was difficult in some cases to determine the plateau (e.g. infant $\mathrm{LH})$. The exponential fit sometimes gives unreliable values; in infant PG the plateau predicted would be more than three times higher than the visual plateau. Waterlow et al. (14) have already discussed these issues in detail and concluded that the visual inspection was the best approach. Assessing the plateau with a second degree polynomial regression has no theoretical background (in contrast to the exponential method), but the estimates proved to be closer to the visual plateau than that computed with the exponential method. Since the second degree polynomial regression provides a more reproducible assessment than the visual inspection, the former approach was used in this study.

When considering whole body protein synthesis, there is still some debate about which of the precursor pools of ammonia or urea represents the best precursor pool for protein synthesis. Some experimental evidence suggests that in addition to glutamine, glycine participates to a greater extent to ammonia formation than the other amino acids (25). This could explain, at least partially, why protein synthesis calculated from ammonia enrichment is $50 \%$ lower than that calculated from urea enrichment. Furthermore, unless the tracer is given with the diet at least at hourly intervals, there may be large fluctuations in ammonia labeling (26) and these fluctuations lead to substantial difficulties in the determination of true plateau. Therefore, the ammonia enrichment method for assessing protein synthesis needs further evaluation; the discussion of the results of this study will be limited to those obtained from urea enrichment.

It should be noted that in five of our studies, urea failed to be enriched; this is in agreement with the results of Jackson et al. (5) who studied very low birth weight infants fed pooled breast milk. Considering the fact that very low birth weight infants did not retain nitrogen as efficiently as in utero, Jackson et al. (5) postulated that glycine availability might be insufficient to meet the high needs for growth. We observed that infants in whom urea failed to be enriched were among those receiving the smallest amount of nitrogen (i.e. $<500 \mathrm{mg} \mathrm{N} / \mathrm{kg}$. day). The total amount of glycine received by the infants (tracer included) ranged from $53 \mathrm{mg} / \mathrm{kg}$. day (infant $\mathrm{CV}_{1}$ ) to $97 \mathrm{mg} / \mathrm{kg}$. day in formula-fed infants. The infant $\mathrm{YR}_{3}$, in whom urea failed to be enriched, received $80 \mathrm{mg} / \mathrm{kg}$. day of glycine and $447 \mathrm{mg} \mathrm{N} / \mathrm{kg}$. day. In this infant, glycine availability does not explain the absence of ${ }^{15} \mathrm{~N}$ enrichment in urea; further studies are needed to explain this phenomenon.

With the ${ }^{15} \mathrm{~N}$ urea enrichment method, the mean rate of protein synthesis was $11.2 \mathrm{~g} / \mathrm{kg}$.day, a value similar to those found in very low birth weight infants by other authors $(4-5,7)$. The relationship between protein synthesis and protein gain (Fig. 4) shows that for each additional gram of protein gained, there is a large increase in protein synthesis, i.e. approximately $5 \mathrm{~g}$. The extrapolation of the line to zero protein synthesis, however, may not be valid since the range of measurements was not extended to values below $0.7 \mathrm{~g}$ of protein gain. For comparison, infants recovering from protein-energy malnutrition, ingesting various levels of energy $(60-270 \mathrm{kcal} / \mathrm{kg} \cdot$ day and $9.2 \%$ protein energy), exhibited a mean protein synthesis rate of $7 \mathrm{~g} / \mathrm{kg} \cdot$ day (27), and an increase of $1.4 \mathrm{~g}$ of synthesis for each gram of protein gained; these values are substantially lower than our respective estimates. The lower "efficiency" of protein gain (i.e. the amount of protein gained per gram of protein synthesis) in very low birth weight infants, as compared to infants recovering from proteinenergy deprivation, remains to be investigated.

Muscle protein breakdown accounted for $13 \%$ of total protein breakdown. Duffy et al. (4) found a similar percentage in very low birth weight infants receiving total parenteral nutrition during the first week of life. If we assume that the creatinine excretion rate in these infants reflects the same amount of muscle protein in the body as found in older children (28) (i.e. $1 \mathrm{~g}$ of muscle protein is associated with a creatinine excretion of $0.25 \mathrm{mg} /$ day), the amount of muscle protein of these very low birth weight infants is about $45 \mathrm{~g} / \mathrm{kg}$ (calculated from Table 7), and their total amount of body protein is approximately $100 \mathrm{~g}(24)$. Thus the contribution of muscle to total protein breakdown (13\%) is much less than the proportion of muscle protein to total body protein $(45 \%)$, indicating that the rapid protein turnover is mainly due to other rapidly growing organs, such as the brain, liver, and viscera.

Relationship between energy expenditure, protein gain, and protein synthesis. In these rapidly growing infants, the total cost of growth (i.e. the energy retained plus the energy cost of new tissue synthesis) represents about half the metabolizable energy, confirming previous results (2). The cost of new tissue synthesis has been estimated to be 19 or $13 \%(1,29)$ of the daily energy expenditure. In the present study it represented a far greater fraction, i.e. $32 \%$ of the resting energy expenditure. From biochemical considerations, the synthesis of tissue protein entails a considerable amount of energy. Therefore, we attempted to see whether the daily resting energy expenditure of these infants was related to their rate of protein synthesis.

The positive relationship existing between resting energy expenditure and protein synthesis was on the borderline of significance $(r=0.53 ; p<0.07)$, probably due to the small number of observations which could be used for this analysis. However, it is also possible to estimate the cost of protein synthesis in an indirect manner. The relationship between protein gain and resting energy expenditure indicates that for each additional gram of protein gained, there is an increase in energy expenditure of $10 \mathrm{kcal}$ (Fig. 5). On the other hand, for each gram of additional protein gain, there is an increase in protein synthesis of $5 \mathrm{~g}$ (Fig. 4). If we assume that all the extra energy expenditure is due to protein synthesis, the cost of protein synthesis would be $2 \mathrm{kcal} /$ $\mathrm{g}(10 \mathrm{kcal} / 5 \mathrm{~g})$. This cost is twice as great as the theoretical cost of protein synthesis calculated from the number of ATP necessary to form peptide bonds $(\sim 1 \mathrm{kcal} / \mathrm{g}$ protein) $(30)$. However, the cost calculated from stoechiometry is minimal. Furthermore, other energy dissipative mechanisms may be involved during growth which are not yet known.

The present study indicates that increase in protein gain in very low birth weight infants is accompanied by a considerable increase in both protein synthesis and breakdown, confirming previous studies (4-7). The substantial increase in protein turnover may be viewed as a physiological phenomenon which allows fast remodeling of body protein during rapid growth. This energetically wasteful process is accompanied by an increase in energy expenditure estimated to be approximately $2 \mathrm{kcal} / \mathrm{g}$ protein synthesized or $10 \mathrm{kcal} / \mathrm{g}$ protein retained. Further studies are needed to understand the mechanisms of these energy dissipative processes.

Acknowledgments. The authors thank Professor E. Gautier for his support in this study and the nursing staff of the Neonatology Division of the Pediatric Clinic for their technical assistance. 


\section{REFERENCES}

1. Gudinchet F, Schutz Y, Micheli JL, Stettler E, Jéquier E 1982 Metabolic cost of growth in very low-birth-weight infants. Pediatr Res 16:1025-1030

2. Reichman BL, Chessex Ph, Putet G, Verellen GJE, Smith JM, Heim T, Swyer PR 1982 Partition of energy metabolism and energy cost of growth in the very low-birth-weight infant. Pediatrics 69:446-451

3. Brooke OG, Wood C, Barley J 1982 Energy balance, nitrogen balance, and growth in preterm infants fed expressed breast milk, a premature infant formula and two low solute adapted formulae. Arch Dis Child 57:898-904

4. Duffy B, Gunn T, Collinge J, Pencharz P 1981 The effect of varying protein quality and energy intake on the nitrogen metabolism of parenterally fed very low-birth-weight $(<1600 \mathrm{~g})$ infants. Pediatr Res 15:1040-1044

5. Jackson AA, Shaw JCL, Barber A, Golden MHN 1981 Nitrogen metabolism in preterm infants fed human donor breast milk: the possible essentiality of glycine. Pediatr Res 15:1454-1461

6. Pencharz PB, Steffee WP, Cochran W, Scrimshaw NS, Rand WM, Young VR 1977 Protein metabolism in human neonates: nitrogen-balance studies, estimated obligatory losses of nitrogen and whole body turnover and nitrogen. Clin Sci Mol Med 52:485-498

7. Pencharz PB, Masson M, Desgranges F, Papageorgiou A 1981 Total body protein turnover in human premature neonates: effects of birth weight, intrauterine nutritional status and diet. Clin Sci 61:207-215

8. Dubowitz LMS, Dubowitz V, Goldberg C 1970 Clinical assessment of gestational age in the newborn infant. J Pediatr 77:1-10

9. Liu HY, Anderson GJ 1967 A method for long-term quantitative and fractiona urine collection. J Pediatr 70:276-279

10. Southgate DAT, Durnin JVGA 1970 Calorie conversion factors. An experimental reassessment of the factors used in the calculation of the energy value of human diets. Br $\mathrm{J}$ Nutr 24:517

11. Brück K 1961 Temperature regulation in the newborn infant. Biol Neonate 3:65-119

12. Picou D, Taylor-Roberts T 1969 The measurement of total protein synthesis and catabolism and nitrogen turnover in infants in different nutritional states and receiving different amounts of dietary protein. Clin Sci 36: 283-296

13. Steffee WP, Goldsmith RS, Pencharz PB, Scrimshaw NS, Young VR 1976 Dietary protein intake and dynamic aspects of whole body nitrogen metabolism in adult humans. Metabolism 25:281-295

14. Waterlow JC, Garlick PJ, Millward DJ 1978 Protein turnover in mammalian tissues and in the whole body. Elsevier North-Holland Biomedical Press, Amsterdam

15. Lunyong VE, Friedman Z 1982 Myofibrillar protein degradation in premature infants with respiratory distress as assessed by 3 methylhistidine and creatinine excretions. Am J Clin Nutr 36:485-491

16. Largo RH, Wälli R, Duc G, Fanconi A, Prader A 1980 Evaluation of perinatal growth. Helv Paediatr Acta 35:419-436

17. Gross St J 1983 Growth and biochemical response of preterm infants fed human milk or modified infant formula. $\mathbf{N}$ Engl $\mathbf{J}$ Med 308:237-241

18. Atkinson SA, Bryan MH, Anderson GH 1981 Human milk feeding in premature infants: protein, fat and carbohydrate balance in the first two weeks of life. J Pediatr 99:617-624

19. Reichman B, Chessex Ph, Putet G, Verellen G, Smith J, Heim T, Swyer R 1981 Diet, fat accretion and growth in premature infants. N Engl J Med 305:1495-500

20. Brooke OG 1980 Energy balance and metabolic rate in preterm infants fed with standard and high-energy formulas. Br J Nutr 44:13-23

21. Spady DW, Payne PR, Picou D, Waterlow JC 1976 Energy balance during recovery from malnutrition. Am J Clin Nutr 29:1073-1088

22. Meurling ST, Artuson G, Zaar B, Erikson G 1981 Energy, fat and nitrogen balance in healthy newborn infants during the first week after birth. Acta Chir Scand 147:487-495

23. Lubchenko LO, Hansman C, Dressler M, Boyd E 1963 Intrauterine growth as estimated from live born birth weight data at 24 to 42 weeks of gestation. Pediatrics 32:793

24. Widdowson EM 1981 Changes in body composition during growth. In: Davies JA, Dobbing $J$ (eds) Scientific Foundations of Paediatrics. Heinemann, London, pp 330-342

25. Pitts RF, Pilckington LA $1965 \mathrm{~N}^{15}$ Tracer studies on the origin of urinary ammonia in the acidotic dog, with notes of the enzymatic synthesis of labeled glutaminc acid and glutamines. J Clin Invest 44:731-745

26. Crane CW, Picou D, Smith R, Waterlow JC 1977 Protein turnover in patients before and after elective orthopaedic operations. Br J Surg 64:129-133

27. Golden M, Waterlow JC, Picou D 1977 The relationship between dietary intake, weight change, nitrogen balance and protein turnover in man. Am J Clin Nutr 30:1345-1348

28. Graystone JE 1968 Creatinine excretion during growth. In: Cheek DB (ed) Human Growth, Body Composition, Cell Growth, Energy and Intelligence. Lea and Febiger, Philadelphia, pp 182-197

29. Chessex Ph, Reichman BL, Verellen GJE, Putet G, Smith JM, Heim T, Swyer PR 1981 Influence of postnatal age, energy intake, and weight gain on energy metabolism in the very low-birth-weight infant. J Pediatr 99:761-766

30. Flatt JP 1980 The biochemistry of energy expenditure. In: Bray G (ed.) Recent Advances in Obesity Research II. John Libbey, London, p 211-18

\title{
The Development of Antioxidant Enzymatic Defense in the Perinatal Rat Lung: Activities of Superoxide Dismutase, Glutathione Peroxidase, and Catalase
}

\author{
EVA GERDIN, OLOF TYDÉN, AND ULF J. ERIKSSON
}

Department of Obstetrics and Gynecology [E.G., O.T.], University Hospital and Department of Medical Cell Biology [U.J.E.], Biomedicum, University of Uppsala, Uppsala, Sweden

\begin{abstract}
This report describes the development of superoxide dismutase, glutathione peroxidase, and catalase activities in fetal (days 16-22) and neonatal (day 2 postpartum) lungs of normal rats. Each of the enzymes showed
\end{abstract}

Received October 19, 1984; accepted March 4, 1985.

Address for correspondence Dr. Eva Gerdin, Department of Obstetrics and Gynecology, University Hospital, S-750 14 Uppsala 14, Sweden.

Supported by the "Expressen" Prenatal Research Foundation, the Memorial Fund of the "Allmänna Barnbördshuset, the Medical Faculty of the University of Uppsala, and the Swedish Medical Research Council (Grants 12x-109, 12P-6346). an individual pattern of development in the perinatal period. Glutathione peroxidase activity increased by $135 \%$ $(p<0.001)$ during the last 3 days before birth, catalase activity by $105 \%(p<0.01)$ during the first 2 postnatal days, and the activity of superoxide dismutase by $52 \%(p$ $<0.05$ ) from gestational day 19 to 2 days after birth. Contamination by superoxide dismutase from blood in the lung samples accounted for less than $2 \%$ of the activity. In contrast, not less than 10-30\% of glutathione peroxidase 